\title{
The Impact of Red Sea on the Temperature and Salinity Profiles of Arabian Sea
}

\author{
Deep Sankar B* \\ Ministry of Earth Sciences, India
}

Submission: February 15, 2017; Published: March 27, 2017

*Corresponding author: Deep Sankar B, Project Scientist - 'B', ESSO-Indian National Centre for Ocean Information Services, Ministry of Earth Sciences, Hyderabad- 500090, India, Email: deepsankarbanerjee@gmail.com

Abstract

The purpose of this experiment is to find out the impact of Red Sea on the temperature and salinity profile of Arabian Sea. To investigate this phenomenon, Regional Ocean Modeling Software (ROMS) is used as a numerical ocean model whose resolution is taken to be quarter degree. In order to compute the effect of Red Sea Water (RSW) on Arabian sea the initial condition of the model is prepared on such a grid where deliberately land mask is imposed such that the whole red sea is covered up to the 'Bab el Mandeb'. After that the model is allowed to run for three years. A model with same configuration and parameters is also allowed to run for the three years, same as that of the previous case with another grid where there is no land mask imposed on Red Sea.

After successful completion of run, a difference is taken between the above two cases for vertical temperature and salinity profiles for an entire year by averaging out the three year monthly data and by selecting a squared region over Western Arabian Sea where a spatial average is taken. From the result it is observed that the difference in salinity between the two cases attains maximum value near the subsurface layer where usually the salinity is seen to be higher in western Arabian Sea during the presence of northeasterly monsoon wind. From the vertical profile of temperature difference between the two cases it is clear that the difference is also appeared to attain a maximum value (about 1 deg C) near the $150 \mathrm{~m}$ depth which is possibly because of the lowering of thermo cline due to the restriction imposed on RSW. It should also be mentioned that both salinity and temperature shows a clear seasonal variation.

Keywords: Red sea; Arabian sea; ROMS; Thermo cline; Gulf of aden

\section{Introduction}

The purpose of this investigation is to study the impacts of high saline Red sea water on Arabian Sea. Section 2 gives some of the salient features climate and structure of the Red Sea. Section 3 deals with the experimental setup and informs about the data and boundary conditions that is used to run the model. It also informs about the two experiments that are performed using the numerical ocean model namely, Regional Ocean Modeling Software (ROMS) in Indian Ocean domain. In the first experiment a grid file and a climatologically forcing are prepared where land mask has been imposed on the Red Sea up to Bab el Mandeb. On the other hand another grid file and climatologically forcing are created without the land mask. With these two initial conditions two models is allowed to run for three years keeping all other parameters and schemes same for both of the cases. The resolution of the model is taken to be $1 / 4$ th degree. Section 4 provides the details of the result from these two experiments by plotting the seasonal variation of differences between temperature and salinity with depth in western Arabian Sea with and without the existence of Red Sea.

\section{Some Important Features of Red Sea}

The Red Sea is a desert-enclosed, narrow basin of about $2000 \mathrm{~km}$ length with an average width of about $300 \mathrm{~km}$. The Red Sea basin is connected to the Indian Ocean and Gulf of Aden through a narrow strait of Bab al Mandeb situated in the south and A deep trench of up to $2500 \mathrm{~m}$ depth runs along the axis of the otherwise shallow sea (average depth about $500 \mathrm{~m}$ ). The only connection of the basin to the open ocean is through the Strait of Bab al Mandeb in the south that links the Red Sea with the Gulf of Aden and thereafter Arabian Sea. [1] The surroundings of the Red Sea are mostly mountains and desert. The climate of the Red Sea is the result of two distinct monsoon seasons a north easterly monsoon and a southwesterly monsoon. Monsoon winds occur because of the differential heating between the land surface and sea. Due to very high surface temperatures coupled with 
high salinities makes it one of the hottest and saltiest bodies of seawater in the world. The average surface water temperature of the Red Sea during the summer is about $26{ }^{\circ} \mathrm{C}$ in the north and $30{ }^{\circ} \mathrm{C}$ in the south, with only about $2{ }^{\circ} \mathrm{C}$ variation during the winter months.

The overall average water temperature is $22^{\circ} \mathrm{C}$. The rainfall over the Red Sea and its coasts is extremely low, averaging $0.06 \mathrm{~m}$ (2.36 in) per year the rain is mostly in the form of showers of short spells often associated with thunderstorms and occasionally with dust storms. Due the scarcity of the rainfall and lack of fresh water intake the Red Sea result in the excess evaporation as high as $205 \mathrm{~cm}$ (81 in) per year and high salinity with minimal seasonal variation. The air temperature of red sea is relatively low in the northern part and increases in southern part. Between $20 \operatorname{degN}$ and $16 \operatorname{degN}$ there exists the warmest region [2].

\section{Experimental Setup and Methodology}

The experiment has been performed using Regional Ocean Modeling Software (ROMS) model. The domain of interest that is chosen is entire Indian Ocean Region. It spans from $30 \mathrm{E}$ to $120 \mathrm{E}$ across longitude and $30 \mathrm{~S}$ to $30 \mathrm{~N}$ across latitude. This is why there are two open boundaries namely, the southern boundary and the eastern boundary. And there exists two closed boundaries as well i.e., the northern boundary and the western boundary. In the model 'Flathered' Lateral Boundary Condition (LBC) is applied in southern and eastern boundary for free surface. 'Chapman' LBC is applied in southern and eastern boundary for 2DU-momentum, 2DV momentum. 'Clamped' LBC is applied in southern boundary and eastern boundary for 3DU Momentum, 3DV Momentum and for the tracer components i.e., Temperature and Salinity. The resolution of the model is taken to be $1 / 4^{\text {th }}$ degree for the entire experiment. The Salinity is relaxed to a climatologically data and due to that the river discharge is turned off while running the model. The mean of an ensemble of forcing and an ensemble of initial condition has been chosen to drive the model for both the cases. The initial condition that was used to drive the model is starting from $4^{\text {th }}$ January 2003. Boundary condition that was used in the model is taken from Simple Ocean Data Assimilation (SODA). To analyse the impact of high saline red sea water on Arabian Sea two initial conditions were developed. First a land mask had been so imposed such that it would mask the entire red sea up to the Bab el Mandeb. With this resulting grid an initial condition and a climatologically forcing is developed for the model.

On the other hand another initial condition was developed where there is no land masking on the Red Sea. Here it has to mention that for both cases while creating initial condition for the model the gulf of Thailand, South China Sea, Celebes Sea and the java sea land mask had been imposed as that is not accounted for the domain of interest. The model was then allowed to run for three years i.e., from the $4^{\text {th }}$ of January 2003 to $31^{\text {st }}$ December 2005. After successful completion of the run a monthly average had been created for the three years.

\section{Results and Discussion}

First a spatial average has been done by selecting a squared area as shown in Figure $1 \& 2$ shows the time-depth series of the absolute difference of salinity between two cases where landmask is imposed on Red Sea and when it is not. It has been done by spatially averaging the data from the region marked by box in (Figure 1). In this plot it is quite clear that the salinity differs at maximum 0.13PSU across the subsurface layers of the ocean i.e., up to the depth of $150 \mathrm{~m}$. The southeastern part of the sea is in contact with the Bay of Bengal and eastern equatorial Indian ocean where precipitation is about $2 \mathrm{~m}$ per year. Average annual evaporation on Arabian sea is about $1.5 \mathrm{~m}$.



Figure 1: SST data of our domain of interest which is achieved by producing monthly average from three year ROMS output while the Red Sea is completely masked by land.

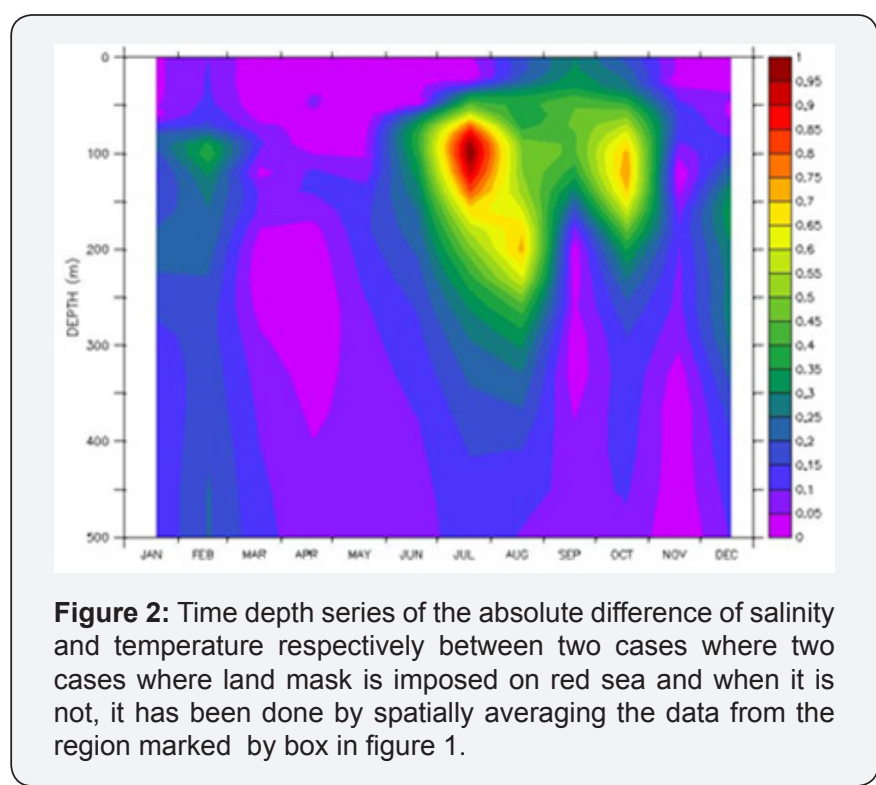

Due to this Arabian sea loses water to the atmosphere as a whole which is due to the high gradient of precipitation minus evaporation. This gradient makes the surface salinity increases with higher salinity in the north. This high saline water in the northern Arabian Sea is often known as ASHSW. In the Red Sea evaporation also exceeds precipitation by over $2 \mathrm{~m}$ per year. As 
a result the Red sea water enters into the Gulf of Aden through the strait of Bab el Mandeb which in turn increases the salinity of Arabian Sea [3]. Whereas to realize the impact of Red Sea Water (RSW) on the Arabian sea the land mask has been imposed on the whole red sea as well as on the Bab el Mandeb.

As a result it restricts the high salinity water of Red Sea from entering into the Arabian Sea which in turn results a slight decrement in salinity. Also due to high precipitation in the southern and eastern part of the North Indian Ocean leads to the formation of equatorial surface water [4] which can be found in the subsurface layers of ocean i.e., about 50-75m depth where salinity increases with depth. During northeast monsoon this water moves into Arabian Sea. As a result a mixing of high salinity water from northern region and low salinity water from southern region occurs. Due to this the low salinity water sinks below and it forms a sub-surface salinity maxima. But due to the imposed restriction of RSW the mixing process got affected somewhat and it changes the vertical salinity profile during the month of October and November (i.e., during the northeast monsoon) this is what is clearly visible in the (Figure 2).

The same process is repeated for the temperature and the resulting plot regarding the time-depth series of the absolute difference of temperature between two cases is shown in Figure 3. It is also done for same region as described previously. An assumption can be made that the water circulation is most affected by the winds. And with this assumption Thompson in 1939 proposed a surface inflow during the winter due to the SSE winds [5]. In the vicinity of the sill a subsurface outflow of warm saline water enters the Gulf of Aden and thereafter it changes the vertical temperature profile of Arabian Sea [6]. Thus if the inflow is restricted from the Red Sea the mixing of warm water will not occur which in turn will cause the lowering of thermo cline level in this region. As a result the temperature difference can easily be expected to attain a higher values in the thermo cline region which can be clearly visible in (Figure 3 ).

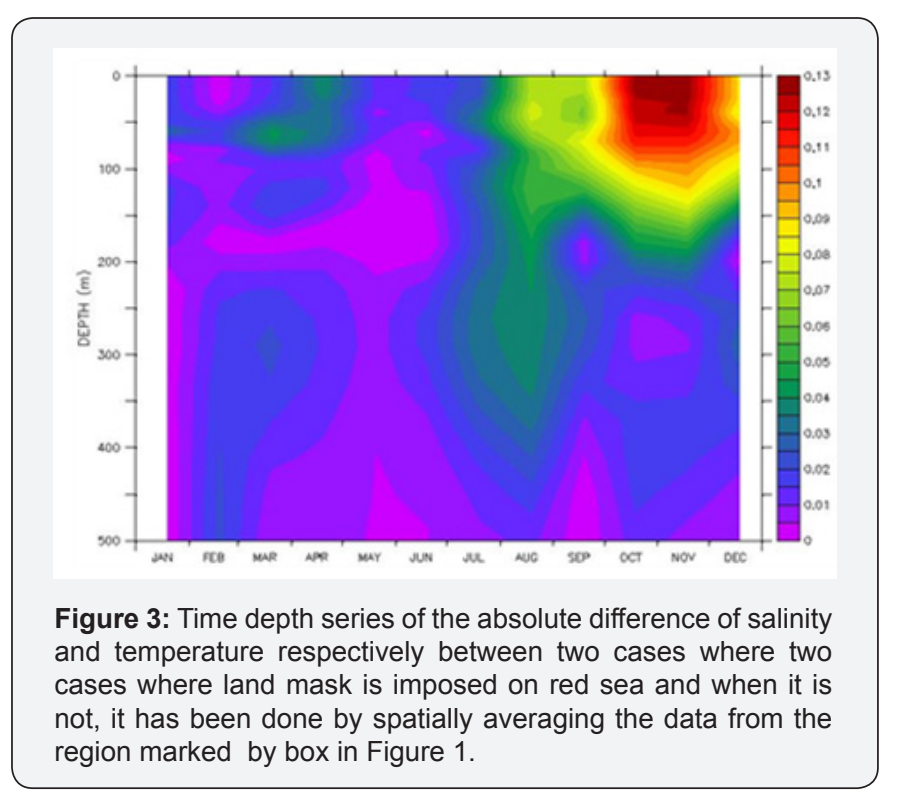

\section{Conclusion and Possible Further Studies}

By performing this experiment it has been observed that the Red Sea clearly governs the salinity and temperature profile of Arabian Sea. If the warm and high saline water inflow from Red Sea into Gulf of Aden is restricted the salinity in the subsurface layers of Western Arabian Sea will decrease particularly during October and November i.e., during northeasterly monsoon. It is also important to note that the restriction imposed on warm water inflow from Red Sea into Gulf of Aden indirectly lowers the thermo cline depth in Western Arabian Sea which in turn can affect the upwelling phenomena near the east coast of Africa. It should also be mentioned that there are no significant change that was found in the sea level across the Arabian sea in the entire experiment. More variability might be seen if the model is allowed to run for further two to three years. It can also be anticipated that more variability can be captured by the model if more high resolution is chosen for the entire experiment [7].

\section{Acknowledgement}

I want to acknowledge the Dr. Balakrishnan Nair TM, Scientist -'G', Head, Information Services and Ocean Sciences Group, ESSO - Indian National Centre for Ocean Information Services, Hyderabad, India for his immense support. I also want to express my sincere gratitude to Dr. Kunal Chakraborty, Scientist - 'D', Dr. Arya Paul, Scientist -'D' ,Information Services and Ocean Sciences Group and Dr. Siva Reddy, Scientist -'C', ESSO-INCOIS, Hyderabad for providing me the data except which these experiments could not be possible. I also want to convey my sincere gratitude to Dr. Francis PA, Scientist - 'F', Information Services and Ocean Sciences Group ESSO-INCOIS Hyderabad for helping me getting accustomed with the Regional Ocean Modeling Software (ROMS). Last but not the least I would also like to express my sincere gratitude to Dr. Shenoi SSC, Director, ESSO-INCOIS, Hyderabad whose guidance always give me the strength to perform something innovative.

\section{References}

1. Maillard C, Soliman G (1986) Hydrography of the Red Sea and exchanges with the Indian Ocean in summer. OCEANOLOGOCA ACTA (9)3: 249-269.

2. Edwards FJ (1987) Climate and Oceanography. In: Edward FJ, Head SM (Eds.), Red Sea-Key environments. Pergamon Press, Oxford, UK, pp. 45-693.

3. Shetye SR, Gouveia AD, Shenoi SSC (1994) Circulation and water masses of Arabian Sea. Indian Acad Sci 103(2): 107-123.

4. Darbyshire M (1967) The surface waters off the coast of kerala, south west India. Deep Sea Res 14(3): 295-320.

5. Neumann CA, David A McGill (1961) Circulation of Red Sea in early summer. Dep Sea Res 8(3-4): pp. 223 -285.

6. Nandkeolyar N, Raman M, Sandhya KG, Jai A (2013) Comparative Analysis of Sea Surface Temperature Pattern in the Eastern and Western Gulfs of Arabian Sea and the Red Sea in Recent Past Using Satellite Data. International Journal of Oceanography 2013: p. 16.

7. Jaswal AK, Virendra S, Bhamba SR (2012) Relationship between sea surface temperature and surface air temperature over Arabian Sea, Bay of Bengal and Indian Ocean. J Ind Geophys Union 16(2): pp. 41-53. 


\section{Your next submission with Juniper Publishers} will reach you the below assets

- Quality Editorial service

- Swift Peer Review

- Reprints availability

- E-prints Service

- Manuscript Podcast for convenient understanding

- Global attainment for your research

- Manuscript accessibility in different formats ( Pdf, E-pub, Full Text, Audio)

- Unceasing customer service

Track the below URL for one-step submission https://juniperpublishers.com/online-submission.php 